\title{
PREREQUISITES FOR THE ESTABLISHMENT OF EDUCATIONAL SOCIETIES IN YELYSAVETGRADSHCHINA IN THE SECOND HALF OF THE XIX - EARLY XX CENTURY
}

\author{
Olena Olizko \\ ${ }^{I}$ Graduate student of the Pedagogy and Education Management Department, Volodymyr Vynnychenko \\ Central Ukrainian State Pedagogical University, Kropyvnytskyi, Ukraine, e-mail: olizko.lena@ukr.net, \\ ORCID: https://orcid.org/0000-0002-3214-6106
}

\begin{abstract}
The process of formation of cultural and educational activities of public societies of Yelisavetgrad region is a part of the whole history of Ukrainian pedagogy, which has a direct and indirect connection with social, cultural, economic, legal, demographic, state-building and other factors. The article reveals the preconditions for the establishment of educational societies in Yelisavetgrad region in the second half of the XIX - early XX century, namely: educational - led to the expansion of the network of educational institutions; political - caused the emergence and territorial expansion of settlements in central Ukraine, where, among other things, the school was built; economic - led to an increase in the population, the main activity of which was agriculture and manufacturing, whose occupations required appropriate knowledge, and therefore encouraged to obtain quality practice-oriented education; socio-cultural - caused an increase in the level of culture of the inhabitants of the region, contributed to the intensification of the educational movement, which led to the emergence of cultural and public societies in the region.

It was found that among the greatest achievements of Yelisavetgrad charity in providing various segments of the population with both basic and special knowledge - rich and diverse activities of Yelisavetgrad Society for Literacy and Crafts, which was founded in 1873 on the initiative of public and cultural figure, teacher MFedorovsky and united around him a large part of the city's intelligentsia and was one of the most successful in the Russian Empire in terms of its activities. The society carried out large-scale educational, pedagogical and educational work on a charitable basis: it promoted the establishment of educational institutions, organized Sunday readings of progressive literature, conducted significant educational and organizational and propaganda work among the population and students, organized theater performances, concerts and art.
\end{abstract}

Keywords: educational societies, preconditions of creation of educational societies, Yelisavetgrad society of distribution of literacy and crafts, educational activity, public initiative.

JEL Classification: I0; I20

Formulas: 0; fig.: 3; tabl.: 0; bibl.: 7

Introduction. The preconditions for the establishment of educational societies in the study region cannot be considered in isolation from the general process of development of the educational movement in the Russian Empire.

In the context of revealing the problem of the development of the enlightenment movement in the Ukrainian lands of the Russian Empire, the period of the second half of the XIX - early XX centuries needs exceptional actualization, because at this time there is a growing community interest in education.

Thanks to the hard work of the progressive part of the intelligentsia of Yelisavetgrad region and with the assistance of progressive public and culturaleducational figures in the region, the preconditions for the establishment of educational societies were created.

Literature review. A significant role in the actualization of the research problem was played by the works of local lore specialists of modern researchers 
I. Bosa [2], V. Boska [3], O. Trybutska [5], O. Filonenko [6], L. Filoretova [7], etc. in which the authors, analyzing the educational activities of the Yelisavetgrad Society for the Dissemination of Literacy and Crafts, note the place and role of individuals in the development of educational institutions and the system of public education in the Yelisavetgrad region. At the same time, the pedagogical and public-educational activity of the Yelisavetgrad Society for the Dissemination of Literacy and Crafts and its members, which carried out large-scale educational, pedagogical and educational work on a charitable basis, contributed to the establishment of educational institutions, remains poorly covered.

Aims. The purpose of the article is to reveal the preconditions for the establishment of educational societies in Yelisavetgrad region in the second half of the XIX - early XX century.

Methods. The historical-logical method made it possible to determine the sociopolitical and social features of social development and their influence on the development of the educational movement in Ukraine in the specified historical period; constructive-genetic method provided an opportunity to determine the sociohistorical and cultural-pedagogical prerequisites for the development of educational societies in Yelisavetgrad region in the second half of the nineteenth - early twentieth century.

Results. From the second half of the XIX century. On the territory of Dnieper Ukraine, which included the Right Bank, Left Bank, Slobozhanshchina region and Southern Ukraine, there were illegal circles, associations, societies, whose main task was to spread education among the people, awakening their national identity. These societies soon became known as Communities. Ukrainian Communities took from the Cyril and Methodius ideas of patriotism, Ukrainophilism and defined their activities as scientific, educational, cultural [4, p. 13]. From the beginning of the first Communities in 1861 until 1907, when they were transformed into Enlightenment societies, the citizens aimed to form the national consciousness and selfconsciousness of the Ukrainian people through enlightenment, dissemination of knowledge, education, literacy of the masses. They considered the organization of Sunday schools with Ukrainian as the language of instruction, ethnographic research, dissemination of the Ukrainian word through printed publications, creation of Ukrainian textbooks for public schools, struggle for the introduction of the Ukrainian language in educational institutions, creation of a national school, and in this context development of content, forms and methods of teaching children and adults [4, p. 10].

Summarizing the experience of educational activities of societies operating in Ukraine, O. Sukhomlynska states that the activities of each of the "Enlightenment" differed in its features due to local circumstances. But they were united by a common goal - "to promote the development of Ukrainian culture, in particular the education of the Ukrainian people in their native language" [3, p. 64]. The task of educators was to:

1) the spread of primary education;

2) replenishment of knowledge of those who graduated from primary schools; 
3) acquaintance of Ukrainians with spiritual and material treasures of the native land;

4) the development of their love and respect for their people;

5) the formation of the desire to work for the good of the nation [3, p. 64].

In the middle of the XIX century. The Russian Empire was experiencing a deep crisis in almost all spheres of life. The essence of this crisis was the inconsistency of existing feudal structures and relations with the world's leading trends. This became especially noticeable after the wave of bourgeois revolutions in Europe (1848-1849), which established a new bourgeois society. Characteristic features and manifestations of the crisis situation in the Russian Empire were [6]:

- decline of landed estates, increasing exploitation of peasants;

- the dominance of regressive methods of management, inhibiting the development of capitalist processes, ie artificial restraint of the formation of the free labor market, industrial development, etc .;

- growing social tensions in society.

The government did not limit itself to judicial, military, peasant and financial reforms. The development of capitalism required changes in the education system, requiring the production of skilled professionals in various fields.

Some liberalization of life in the Russian Empire contributed to the intensification of the democratic part of society, which, in turn, advocated the introduction of universal education.

The intelligentsia also condemned the class character of the school, supported the development of education, and so on. For the first time in the history of the empire, pedagogical problems began to be widely discussed by the public. Moreover, they have become the subject of many public initiatives. Thus, at the turn of the 5060 s of the XIX century. the educational life of the country was enriched by a new phenomenon - the emergence of social and pedagogical movement.

In addition, the advanced intelligentsia was well aware that government measures not only remained on paper, but profoundly and radically changed the course and direction of people's lives in its progressive, progressive, socio-cultural development, it was necessary to prepare the masses for major educational reforms. A possible way for such development could be to create conditions for access to primary education for all segments of the population. Education, thus, could become the only driving force for the development of not only mental but also moral strength of the people [4, p. 12].

In 1864, the government carried out an educational reform of the school, the essence of which was to create a unified system of education. As a result of the school reform, a unified system of primary education was introduced. Primary education was provided by primary public schools, which worked according to a single curriculum. The purpose of these institutions was to teach students the Law of God, reading, writing, and the four acts of arithmetic. The educational process throughout the Russian Empire was carried out in Russian.

Thanks to the reforms of the 60's of the XIX century. education and training became a public affair, which was reflected in the internal structure of schools. The 
management of public schools passed to the county and provincial school councils, and the maintenance of educational institutions became the responsibility of the local population and the zemstvo.

However, these changes were not rapid, as they were determined primarily by socio-economic conditions and autocratic policy in the field of education, and the proclaimed idea of universal education did not change in practice the class nature of education [6, p. 54].

Scientific research shows that the period of the second half of XIX - early XX centuries. was one of the most complex and dynamic in the history of national education. Changes in the whole structure of the Russian Empire and the needs of economic development in the new conditions required adequate provision, including human resources. The rapid development of scientific and technological progress and market relations has significantly exacerbated the increase in requirements for general education and training. Public educational activities, which offered new, more democratic and progressive ways of educational evolution, also became noticeably more active. Cultural and educational activities of the public in the second half of the XIX - early XX century became extremely relevant and intense.

At this time, civil society began to develop - various organizations, associations, groups were created, which had different goals and objectives, generally criticized the state of affairs, pushed the government to radical change in various fields, and in particular in education. There are Communities whose members raise issues of national education, schooling and publication of educational literature in Ukrainian [7, p. 124].

As a rule, representatives of the local aristocracy and intelligentsia became the founders of various centers of education: educational institutions, educational societies, and so on. With inevitable obstacles, but persistently and systematically, such activities continued throughout the second half of the XIX - early XX centuries. With each passing year, it became more visible and tangible, more and more widespread and qualitatively deepened, despite serious government opposition. The persistence of the public forced the government in some cases to yield to it. However, these were the exception rather than the rule.

From the above follows the following prerequisites for the creation of legal public throughout the Russian Empire: the need to direct the forces of the intelligentsia to solve complex scientific, educational, industrial, commercial, military and other issues; the need to reform school education, which required the creation of various associations to address pedagogical issues. The activity of the educational movement in the Ukrainian lands of the Russian Empire was conditioned by positive changes within the Ukrainian society, the activity of progressive pedagogical forces, the formation of a new generation of intellectuals, the desire of the Ukrainian intelligentsia to consolidate in order to enlighten the Ukrainian people.

Thus, the middle of the XIX century. for the Russian Empire is characterized by the fact that, on the one hand, there was a need to create such types of organizations as educational societies, on the other - there are conditions for this. 
60's of the XIX century. were a time of progressive changes and shifts in the social life of the entire Russian Empire, which included the Kherson province, which could not but affect the development of education in the Yelisavetgrad region.

The reforms of the 60's and 70's intensified the process of development and expansion of the network of educational institutions in the territory of the Russian Empire [6, p. 54]. Fateful for the Russian Empire in general, and for Ukraine in particular, was 1861. It is the starting point in the development of Yelisavetgrad: in 1861 the city was transferred to the civil service, and soon (1865) restored to the status of county center.

At this time, economic and cultural development was revived in Yelisavetgrad a public meeting and a public library were organized in the city, for which books were donated by representatives of the local intelligentsia. Carrying out the reform of city self-government (1871) in Yelisavetgrad not only increased the living standards of citizens, but also intensified the development of primary and secondary education [6, p. 65].

In Yelisavetgrad region, in accordance with the Regulations of July 14, 1864, gradually began to open city folk schools, Sunday schools, men's gymnasium, began public readings, etc. [77, p. 23, 166-169].

The activities of the schools of Yelisavetgrad district were coordinated by the Kherson zemstvo, introduced in 1865 after the approval of the "Regulations on zemstvo institutions" (1864). According to the division of the Ministry of Education, it was part of the Odessa educational district. According to the document, the zemstvos were to control and ensure the improvement of cities, construction of roads, water supply, etc., as well as to expand the school network. However, their rights extended to a greater extent only to economic problems. The educational process was controlled by the Ministry of Public Education and the Synod through provincial and county school councils, principals and inspectors of public schools [6, p. 61]. However, as we are convinced by the reports of the Zemsky Zbor and other primary sources, this local authority made a lot of efforts not only to expand the network of primary schools in Yelisavetgrad district in the second half of the XIX - early XX centuries, but also contributed to improving the educational process. supporting these educational institutions financially (funds were allocated for the purchase of visual aids, books, etc.). In addition, after the Government's prospects for agrarian development of the southern regions of Russia, local authorities allocated small plots of land for school gardens, orchards, etc., ie, created conditions for the practical study of the basics of agricultural production to increase its productivity.

The county also contributed to the expansion of educational space in the Yelisavetgrad region. Thus, as early as 1873, representatives of the Yelisavetgrad Zemstvo appealed to the government of tsarist Russia with a request to introduce general primary education. Particular attention was paid to the expansion of the content of the educational process in primary school as a basis for further learning and human development. Representatives of the county stressed that the tasks of primary education can not be limited to the acquisition of basic literacy, and justified the need to extend the period of study at this stage of education to four years [7]. 
It was thanks to the zemstvo in Yelisavetgrad that the first secondary school was established and maintained - Yelisavetgrad Zemstvo Real School (1870). The county had a positive attitude to the opening of an archeological museum, evening drawing classes and the publication of the first in Ukraine independent of the Ministry of Public Education magazine "Pedagogical Bulletin" (1881-1883) [2, p. 111-112].

Thus, both on the part of state structures and on the part of the public, in Yelisavetgrad there is not only an understanding of the need to solve the problem of vulnerable groups, but also an attempt to solve these problems.

Scientific research has shown that in the history of Yelisavetgrad region in the pre-revolutionary period there was a significant number of patrons who contributed to the development of culture, art, education, science, medicine and other fields.

Discussion. It should be noted the positive dynamics in the process of sociocultural development of Yelisavetgrad region, during which, with the assistance of cultural and public figures, the necessary conditions for the development and dissemination of education in the study region were created.

A special place in the socio-cultural process of Yelisavetgrad region is occupied by local leaders of the cultural and educational movement - N. Braker, M. Zavadsky, P. Ryabkov, O. Pashutin, M. Fedorovsky, V. Khartsiev, etc., who actively participated in the development of education and culture of the region. .

Enlightenment ideas demanded new non-standard initiatives, and the very realization of this prompted the intelligentsia of Yelisavetgrad to unite around the idea of creating an educational society. Thanks to the hard work of the progressive part of the intelligentsia of Yelisavetgrad region and with the assistance of progressive public and cultural-educational figures in the region, the preconditions for the establishment of educational societies were created.

The leading trend of cultural development in the region was the emergence of cultural and social societies, which was a characteristic phenomenon in the Russian Empire in the late nineteenth century. Cultural and public organizations performed a great educational work and thus raised the level of general culture of the population. In particular, in the Yelisavetgrad region the work of the Society for the Dissemination of Literacy and Crafts, which was founded in 1873 on the initiative of public and cultural figure, teacher M. Fedorovsky and united around a large part of the city's intelligentsia and was one of the most successful in the Russian Empire. consequences of their activities [5, p. 8].

Thus, the socio-cultural preconditions for the creation of public societies in the Yelisavetgrad region include the following: the revolutionary movement of the midnineteenth century. and the resulting government reforms, liberalization of life, which led to a revival of activity of a wide range of progressive pedagogical forces, the advanced intelligentsia of the region and a large group of members of the public, the desire of local intelligentsia to consolidate for education.

Conclusions. Thus, the analyzed preconditions contributed to the development of the educational movement in Yelisavetgrad region in the second half of the XIX early XX centuries, namely: educational - led to the expansion of the network of educational institutions; political - caused the emergence and territorial expansion of 
settlements in central Ukraine, where, among other things, the school was built; economic - led to an increase in the population, the main activity of which was agriculture and manufacturing, whose occupations required appropriate knowledge, and therefore encouraged to obtain quality practice-oriented education; socio-cultural - caused an increase in the level of culture of the inhabitants of the region, caused the private initiative of public figures the emergence of cultural and public societies in the region.

The process of formation of cultural and educational activities of public societies of Yelisavetgrad region is a part of the whole history of Ukrainian pedagogy, which has a direct and indirect connection with social, cultural, economic, legal, demographic, state-building and other factors.

\section{References:}

1. Bosa, I. O (2011), Rol 'Tovarystva poshyrennya hramotnosti ta remesel u khudozhn'omu zhytti Yelysavethrada na mezhi XIX - XX stolit' [The role of the Society for the Dissemination of Literacy and Crafts in the artistic life of Yelisavetgrad at the turn of the XIX - XX centuries], Ukrayins'ke mystetstvoznavstvo: materialy, doslidzhennya, retsenziyi, Vyp. 11, p. 145-150. [Ukraine]

2. Bosko, V. M. (2004), Vyznachni become Stepovoyi Ellady: do 250-richchya zasnuvannya fortetsi Svyatoyi Yelyzavety, mista Yelysavethrada ta 65-richchya utvorennya Kirovohrads'koyi oblasti [Prominent figures of Steppe Greece: to found 250th anniversary of the fortress of St. Elizabeth, the city of Yelisavetgrad and the 65th anniversary of the Kirovograd region], Kirovohrad: Informatsiyna merezha, CH. 1,p. 376 [Ukraine]

3. Narysy istoriyi ukrayins'koho shkil'nytstva 1905-1933, (1996) [Essays on the history of Ukrainian schooling 1905-1933], za red. O. V. Sukhomlyns'koyi, K .: Zapovit, p. 304 [Ukraine]

4. Pobirchenko N.(2000), Pedahohichna i prosvitnyts'ka diyal'nist 'ukrayins'kykh hromad u druhiy polovyni XIX - na pochatku XX st. [Pedagogical and educational activities of Ukrainian communities in the second half of the XIX and early XX centuries]: U 2 kn., K : Naukovyy svit, 2000, Kn. 1: Kyyivs'ka hromada. P. 307 [Ukraine]

5. Trybutska O. A. (2012). Yelysavethradske blahodiyne tovarystvo [Yelisavetgrad Charitable Society], Narodne slovo, April 26, p. 8. [Ukraine]

6. Filonenko O. V. (2017). Osvita Kirovohradshchyny (Yelysavethradshchyny) v naukovykh refleksiyakh ukrayins'kykh uchenykh (druha polovyna XIX - XX stolittya) [The Education of the Kirovograd Region (Yelisavetgrad Region) in Scientific Reflectionsf Ukrainian Scientists Second XIX - XX centuries], Kharkiv: Machulyn, p. 412 [Ukraine]

7. Filoretova L. M (2011). Yelysavethradska hromada [Yelisavetgrad community], Naukovyy chasopys NPU im. Dragomanov. Series 6: historical sciences. K., Issue. 9, p. 123-130. [Ukraine] 